\title{
ANALISIS PERILAKU, KEPUASAN DAN LOYALITAS KONSUMEN DALAM MEMBELI PRODUK KOSMETIK MEREK BATRISYIA HERBAL (Studi Kasus pada Masyarakat Dusun Sido Dadi Desa Terentang Baru)
}

\author{
Afriantoni $\left.^{1}\right)$, Ernawati ${ }^{2}$ ) \\ ${ }^{1,2)}$ Staf Pengajar STIE Graha Karya Muara Bulian
}

\begin{abstract}
Abstrak
Penelitian ini bertujuan untuk mengetahui tanggapan responden mengenai perilaku, kepuasan dan loyalitas konsumen pada Dusun Sidodadi Desa Terentang Baru. Populasi yang digunakan adalah masyarakat Dusun Sidodadi dan jumlah sampel yang digunakan dalam penelitian ini berjumlah 56 orang, sampel penelitian ini masyarakat yang menggunakan produk. Hasil penelitian ini menunjukkan bahwa tanggapan responden mengenai perilaku kategori baik, tanggapan responden mengenai kepuasan kategori puas, dan tanggapan responden mengenai loyalitas kategori loyal.
\end{abstract}

Kata Kunci: Perilaku, Kepuasan, Loyalitas

\section{PENDAHULUAN}

\section{Latar Belakang}

Perilaku konsumen di zaman sekarang cenderung berubah-ubah. Tentunya hal ini juga tidak lepas dari kemajuan ekonomi di Negara-negara Asia, yang memberi dampak pada peningkatan pendapatan individual, sehingga konsumen di zaman sekarang lebih berorientasi pada nilai suatu produk dari pada harganya. Konsumen rela untuk membelanjakan uang lebih dengan tujuan mendapatkan pelayanan yang baik, yang tentunya memberi nilai kepuasan kepada konsumen. Salah satu faktor yang dapat mempengaruhi perilaku konsumen adalah gaya hidup. Gaya hidup akan mempengaruhi penilaian yang akan dilakukan oleh seseorang yang akan membeli suatu produk. Gaya hidup menunjukkan pola kehidupan orang yang bersangkutan yang tercermin dalam kegiatan sehari-hari, minat, dan pendapatnya terhadap suatu hal yang sudah melekat pada diri personal seseorang.

Gaya hidup apabila digunakan oleh pemasar secara cermat, dapat membantu untuk memahami nilai-nilai konsumen yang terus berubah dan bagaimana nilai-nilai tersebut dapat mempengaruhi perilaku konsumen. Karena mereka juga memikirkan apa yang mereka pakai sehari-hari. Begitu juga dengan sikap konsumen merupakan faktor penting yang perlu dipahami oleh pemasar karena sikap dianggap mempunyai korelasi yang positif dan kuat terhadap keputusan pembelian.

Loyalitas pelanggan memegang peranan sangat penting dalam organisasi bisnis atau usaha yang dilakukan. Loyalitas pelanggan meliputi komponen sikap dan komponen perilaku pelanggan. Komponen sikap pelanggan merupakan gagasan seperti niat kembali untuk membeli produk atau layanan tambahan dari perusahaan yang sama, kesediaan merekomendasikan komitmen pada perusahaan kepada oang lain, demonstrasi komitmen kepada perusahaan dengan menunjukkan perlawanan jika ada keinginan beralih ke pesaing lain dan kesediaan untuk membayar dengan harga premium. Di sisi lain, aspek perilaku loyalitas pelanggan merupakan pembelian berulang yang sebenernya dari produk atau jasa, yang meliputi pembelian lebih banyak dari produk atau jasa yang sama atau alternatif produk yang lain dari perusahaan yang sama, merekomendasikan perusahaan kepada orang lain dan kemungkinan penggunaan produk dalam jangka panjang untuk merek tersebut masih tetap terjaga kualitasnya (Saravanakumar, 2014). 
Wanita pada dasarnya identik dengan kosmetik. Kosmetik merupakan barang yang dibutuhkan di kalangan wanita yang menyukai penampilan cantik dan percaya diri. Masyarakat Dusun Sidodadi Desa Terentang Baru pada umumnya apabila berpergian tidak hanya berpakaian rapi, tetapi juga memakai riasan wajah, seperti bedak, pelembab bibir, perona pipi, mascara dan lain-lain supaya terlihat lebih cantik. Masyarakat yang sebagian besar lebih suka menggunakan kosmetik dengan merek yang terkenal dan berkualitas. Dimana kualitas ditentukan oleh pandangan dan pengalaman mereka terhadap suatu produk. Produk kosmetik yang sudah mendunia seperti Batrisya Herbal yang begitu familiar di telinga juga tersebar di seluruh Indonesia. Batrisya Herbal merupakan salah satu merek kosmetik yang berbahan herbal dari Indonesia dengan omset miliaran per tahun. Batrisya Herbal adalah produk kosmetik yang didirikan pada tahun 2010 oleh Fatimah AzZahra di Indonesia. Batrisya Herbal memiliki keunggulan yaitu menggabungkan unsurunsur seperti ukuran, gaya, warna, memberikan rasa menawan pada wajah. Walaupun kosmetik Batrisya Herbal sedikit lebih mahal dibandingkan produk kosmetik lainnya namun minat masyarakat Dusun Sidodadi Desa Terentang Baru untuk memilih kosmetik Batrisya Herbal lebih tinggi. Berdasarkan uraian di atas, maka peneliti tertarik untuk mengadakan penelitian dengan judul "Analisis Perilaku, Kepuasan dan Loyalitas Konsumen Dalam Membeli Produk Kosmetik Merek Batrisyia Herbal (Studi Kasus Masyarakat Dusun Sido Dadi Desa Terentang Baru)".

\section{Masalah Penelitian}

1. Bagaimana tanggapan responden tentang perilaku konsumen, kepuasan konsumen, dan loyaliatas konsumen dalam membeli produk kosmetik merek Batrisya Herbal?

2. Bagaimana analisis perilaku, kepuasan dan loyalitas konsumen dalam membeli produk kosmetik merek Batrisyia Herbal?

\section{Tujuan Penelitian}

Adapun tujuan penelitian yang ingin dicapai dari penelitian ini adalah untuk mengetahui tanggapan responden tentang Prilaku Konsumen, Kepuasan Konsumen dan Loyalitas Konsumen dalam membeli produk kosmetik batrisya herbal di Sidodadi Desa Terentang Baru.

\section{TINJAUAN PUSTAKA}

\section{Konsep Prilaku Konsumen}

Perilaku konsumen (consumer behavior) dapat didefinisikan sebagai kegiatankegiatan individu yang secara langsung terlibat dalam mendapatkan dan mempergunakan barang-barang dan jasa-jasa, termasuk di dalamnya proses pengambilan keputusan pada persiapan dan penentuan kegiatan-kegiatan tersebut. Ada dua elemen penting dari arti perilaku konsumen itu : (1) proses pengambilan keputusan, dan (2) kegiatan fisik,yang semua ini melibatkan individu dalam menilai, mendapatkan dan mempergunakan barangbarang dan jasa-jasa ekonomis.

Perilaku konsumen akan menentukkan proses pengambilan keputusan dalam pembelian mereka, proses tersebut merupakan sebuah pendekatan penyesuaian masalah yang terdiri dari lima tahap yang dilakukan konsumen, kelima tahap tersebut adalah pengenalan masalah, pencarian informasi, penilaian alternatif, membuat keputusan, dan perilaku pasca pembelian (Kotler, 2004).

\section{Proses Pembelian Konsumen}

Tahapan proses pembelian dapat juga dianalisis sebagai urutan perilaku sebagaimana yang disajikan pada bagan dibawah ini. Walaupun urutan tahapan tersebut adalah logis, namun menurut Peter dan Olson (1996) ada beberapa hal perlu diperhatikan: 
a. Tidak setiap pembelian mengikuti urutan tersebut dan mensyaratkan bahwa semua aspek perilaku harus dilakukan.

b. Model ditunjukan hanya untuk mendeskripsikan satu jenis urutan perilaku pembelian eceran; sehingga model dapat dikembangkan untuk jenis pembe-lian yang lain.

c. Waktu yang diperlukan untuk melakukan setiap tahapan bervariasi tergantung beberapa faktor.

d. Setiap lembaga pemasaran yang terlibat dalam saluran pemasaran mempunyai penekanan berbeda dalam rangka mendorong perilaku.

Konsep Keputusan Konsumen Dalam Pembelian Produk

1. Keputusan; Keputusan berarti pilihan, yaitu pilihan dari dua atau lebih kemungkinan. Namun, hampir tidak merupakan pilihan antara yang benar dan yang salah, tetapi yang justru sering terjadi ialah pilihan antara yang "hampir benar" dan yang "mungkin salah".

2. Faktor-faktor yang Mempengaruhi Keputusan Pembelian Tjiptono (2006:296) faktorfaktor yang mempengaruhi keputusan pembelian adalah ikatan emosional yang terjalin antara pelanggan dan produsen setelah pelanggan menggunakan produk dan jasa dari perusahaan dan mendapati bahwa produk atau jasa tersebut memberi nilai tambah. Dimensi nilai terdiri dari 4, yaitu :

a. Nilai emosional, utilitas yang berasal dari perasaan atau afektif atau emosi positif yang ditimbulkan dari mengkonsumsi produk. Kalau konsumen mengalami perasaan positif (positive feeling) pada saat membeli atau menggunakan suatu merek, maka merek tersebut memberikan nilai emosional. Pada intinya nilai emosional berhubungan dengan perasaan, yaitu perasaan positif apa yang akan dialami konsumen pada saat membeli produk.

b. Nilai sosial, utilitas yang didapat dari kemampuan produk untuk meningkatkan konsep diri-sosial konsumen. Nilai sosial merupakan nilai yang dianut oleh suatu konsumen, mengenai apa yang dianggap baik dan apa yang dianggap buruk oleh konsumen

c. Nilai kualitas, utilitas yang didapat dari produk karena reduksi biaya jangka pendek dan biaya jangka panjang.

d. Nilai fungsional adalah nilai yang diperoleh dari atribut produk yang memberikan kegunaan (utility) fungsional kepada konsumen nilai ini berkaitan langsung dengan fungsi yang diberikan oleh produk atau layanan kepada konsumen.

\section{Proses Keputusan Konsumen}

Proses pengenalan konsumen meliputi antara lain :

1. Proses Keputusan Konsumen: Pengenalan Kebutuhan, Pencarian Informasi, dan Evaluasi Alternatif.

2. Proses Keputusan Konsumen: Pembelian, Konsumsi, dan Kepuasan.

3. Tanggung Jawab Sosial terhadap Konsumen.

4. Iklan yang Menyesatkan dan Mengelabui Konsumen.

\section{Model-Model Perilaku Konsumen}

Seperti yang telah disebutkan, mempelajari atau menganalisa perilaku konsumen adalah sesuatu yang sangat kompleks, terutama karena banyaknya variabel yang mempengaruhinya dan kecenderungannya untuk saling berinteraksi. Model dari perilaku konsumen dikembangkan sebagai usaha untuk mempermudahnya, sebuah model penyederhanaan gambaran dari kenyataan. Penyederhanaan ini melalui pengaturan aspekaspek dari kenyataan dan hanya terdiri dari aspek-aspek dimana pembuat model tertarik. Sebagai contoh, bila kita mengartikan perilaku konsumen sebagai suatu proses 
pengambilan keputusan, maka titik berat model adalah pada proses tersebut. Bentuk model dapat bermacam-macam, model dapat merupakan uraian secara verbal, atau dengan mempergunakan simbol-simbol matematis. Model perilaku konsumen kebanyakan diuraikan secara verbal. Model dikembangkan untuk berbagai macam penggunaan, tetapi tujuan utama dari pengembangan model perilaku konsumen adalah: (1) Membantu kita untuk mengembangkan teori yang mengarahkan penelitian perilaku konsumen. (2) Sebagai bahan dasar untuk mempelajari pengetahuan yang terus berkembang tentang perilaku konsumen.

Berikut ini adalah bahasan model-model perilaku konsumen yang cukup terkenal yaitu:

1) Model Howard-Sheth

Pembahasan perilaku konsumen dalam sebuah model yang menyeluruh telah diusulkan oleh Howardpada tahun 1963. Tetapi model ini baru dipublikasikan dalam buku "The Theory of Buyer Behavior" di tahun 1969 oleh John A. Howarddan Jagdish N. Sheth, sehingga lebih dikenal sebagai model Howard-Sheth. Model tersebut dapat dipakai untuk membantu dalam menerangkan dan memahami perilaku konsumen meskipun tidak dapat meramalkannya secara tepat.

2) Model Engel, Kollat dan Blackwell

Engel, kollat dan Blackwell telah mengembangkan model untuk menganalisa faktorfaktor yang mempengaruhi perilaku konsumen yang menyebabkan terjadinya keputusan pembelian. Model ini menggambarkan dengan jelas dari mulai timbulnya kebutuhan sampai tahap akhir dari suatu pembelian, yaitu penilaian setelah pembelian. Pendekatan berikutnya didasarkan pada proses pengambilan keputusan konsumen.

Tahap dasar dari proses pembelian menurut model ini: (1) Motivasi, (2) Pengamatan, dan (3) Proses Belajar. Kemudianditeruskan dengan pengarud dari kepribadian, sikap dan perubahan sikap, yang bekerja bersama pengaruh dari aspek sosial dan aspek kebudayaan. Setelah itu baru sampai pada tahap proses pengambilan keputusan. Engel, Kollat dan Blackwell menyebutkan juga bahwa mempelajari perilaku konsumen adalah hampir sama dengan mempelajari perilaku manusia, sejak konsumsi barang-barang ekonomis menjadi dorongan bagi setiap kegiatan manusia.

3) Model Nicosia

Fransesco Nicosia sebenarnya adalah orang yang pertama kali membuat model perilaku konsumen yang menyeluruh. Model Nicosia didasarkan pada teknik gambar aliran proses computer dengan umpan baliknya.Anggapan dari model ini adalah bahwa konsumen belum mempunyai perjalanan langsung tentang produk tertentu atau merek tertentu. Jadi, dimulai dari sebelum terjadinya sebuah pembelian.

4) Model Andreasen

Alan R. Andreasen mengembangkan model umum perilaku konsumen (langganan) yang dibangun dari konsepsi-konsepsi tentang formasi sikap dan perubahannya dalam psikologi sosial. Andreasen, pembuat model ini, meyebutkan bahwa yang menyebabkan perubahan sikap ditentukan oleh berbagai macam jenis informasi, baik sengaja maupun tidak disengaja. Model ini menjelaskan seluruh proses dari rangsangan-rangsangan sampai dengan hasilnya yang berupa perilaku, dan semuanya terkandung dalam siklus pemrosesan informasi, yang terdiri dari 4 tahap, yaitu input berupa rangsangan (stimuli), pengamatan (perception) dan penyaringan, perubahan-perubahan sifat, serta macam hasil yang mungkin terjadi. Titik model Andreasenadalah pada formasi sikap dan perubahan sikap. Manajemen pemasaran yang mencoba untuk mempengaruhi sikap melalui produk dan jaringan komunikasi perusahaan akan dapat mengubah cara mengamatan seseorang konsumen terhadap produk perusahaan. 
5) Model Clawson

Model Clawson lebih menitikberatkan pentingnya perilaku proses pengambilan keputusan untuk membeli dari keseluruhan perilaku konsumen. Perilaku ko nsumen dipengaruhi oleh hasil konflik psikologis dalam berbagai situasi, yang mungkin berupa konflik berat. Clawson menganalisa kedalaman masing-masing bidang dari teori bidang Lewin yang dapat diterapkan pada perilaku pemasaran, khususnya perilaku konsumen dan menunjukkan terjadinya tekanan-tekanan dan reaksi-reaksi psikologis yang dialami konsumen pada bermacam-macam situasi pembeli.

\section{Mengukur Kepuasan}

Kaitan antara kepuasan pelanggan dengan kesetiaan pelanggan tidak bersifat proporsional. Andaikan kepuasan pelanggan diberi peingkat dengan skala satu sampai lima, pada level kepuasan pelanggan yang sangat rendah (level satu), para pelanggan cenderung menjauhi perusahaan dan menyebarkan cerita jelek tentang perusahaan tersebut. Pada level dua sampai empat, pelanggan agak puas, tapi masih merasa mudah untuk beraliih ketika tawaran yang lebih baik muncul. Pada level lima, pelanggan cenderung membeli ulang dan bahkan menyampaikan cerita pujian tentang perusahaan. Kepuasaan atau rasa senang yang tinggi mencptakan ikatan emosional dengan merek atau perusahaan tersebut, tidak sekedar kelebih-sukaan rasional.

Bila pelanggan menilai kepuasan mereka berdasarkan satu unsur kinerja perusahaan katakanlah penyerahan (delivery) perusahaan perlu mengakui bahwa para pelanggan penyerahan lebih awal, tepat waktu, penyelesaian pesanan, dan lain-lain. Peruusahaan juga harus menyadari bahwa dua pelanggan bisa dilaporkan sebagai "sangat puas" dengan alasan yang berbeda. Seseorang mungkin sulit untuk dipuaskan, tetapi puas pada kesempatan ini.

\section{Mutu Produk dan Jasa}

Kepuasan juga akan tergantung pada mutu produk dan jasa. Beberapa pakar telah mendefinisikan mutu sebagai "kesesuaian dengan pengguanaan," "kesesuaian dengan perssyaratan," "bebas dari penyimpangan," dan sebagainya. Kita akan menggunakan definisi dari American Society For Quality Control: mutu adalah keseluruhan fitur dan sifat produk atau pelayanan yang berpengaruh pada kemampuannya untuk memuaskan kebutuhan yang dinyatakan atau yang tersirat. Itu jelas merupakan definisi mutu yang berpusat pada pelanggan. Kita dapat mengatakan bahwa penjual telah mengahasilkan mutu bila produk atau pelayanan penjual tersebut memenuhi atau melebihi harapn pelanggan.

\section{Mengukur Nilai Seumur Hidup Pelanggan}

Kasus pemaksimalan profitabilitas pelanggan jangka panjang ditangkap dalam konsep nilai seumur hidup pelanggan. Nilai seumur hidup pelanggan (CLV-Customer Life Value) menggambarkan nilai sekarang arus laba masa depan yang diharapkan selama pembelian seumur hidup pelanggan. Perusahaan harus mengurangi pendapatan yang diharapkan biaya untuk menarik, menjual, melayani pelanggan itu, menerapkan tingkat diskon yang memadai (misalnya, 10\%-20\%), tergantung pada biaya dari sikap terhadap modal dan risiko. Beragam estimasi telah dibuat atas produk dan jasa yang berbeda.

\section{Ekuitas Pelanggan}

Ekuitas pelanggan adalah total nilai seumur hidup semua pelanggan perusahaan yang didiskontokan, semakin setia pelanggan, maka semakin tinggi ekuitas pelanggan. Rust, Zeithaml, dan Lemon membedakan tiga faktor (drivers) yang mempengaruhi ekuitas pelanggan: ekuitas nilai, ekuitas merek dan ekuitas relasional. 


\section{Loyalitas Pelanggan}

Menurut Secara harfiah loyal berarti setia, atau loyalitas dapat diartikan sebagai suatu kesetiaan. Kesetiaan ini timbul tanpa adanya paksaan, tetapi timbul dari kesadaran sendiri pada masa lalu. Usaha yang dilakukan untuk menciptakan kepuasan konsumen lebih cenderung mempengaruhi sikap konsumen. Sedangkan konsep loyalitas konsumen lebih menekankan kepada perilaku pembeliannya.

Loyalitas pelanggan merupakan salah satu tujuan inti yang diupayakan dalam pemasaran modern. Hal ini dikarenakan dengan loyalitas diharapkan perusahaan akan mendapatkan keuntungan jangka panjang atas hubungan mutualisme yang terjalin dalam kurun waktu tertentu. Menurut Ali Hasan (2008:83) loyalitas pelanggan didefinisikan sebagai orang yang membeli, khususnya yang membeli secara teratur dan berulang-ulang. Pelanggan merupakan seseorang yang terus menerus dan berulang kali datang kesuatu tempat yang sama untuk memuaskan keinginannya dengan memiliki suatu produk atau mendapatkan suatu jasa dan membayar produk atau jasa tersebut.

Menurut Gremler dan Brown (dalam Ali Hasan, 2008:83) bahwa loyalitas pelanggan adalah pelanggan yang tidak hanya membeli ulang suatu barang dan jasa, tetapi juga mempunyai komitmen dan sikap yang positif terhadap perusahaan jasa, misalnya dengan merekomendasikan orang lain untuk membeli.

\section{METODE PENELITIAN}

\section{Objek Penelitian}

Objek penelitian ini adalah analisis perilaku, kepuasan dan loyalitas konsumen dalam membeli produk kosmetik khususnya produk merek Batrisyia Herbal. Lokasi penelitian merupakan tempat melakukan kegiatan penelitian guna memperoleh data yang berasal dari responden. Lokasi penelitian ini dilakukan di Dusun Sidodadi Desa Terentang.

\section{Populasi dan Sampel}

Populasi dalam penelitian ini adalah masyarakat Dusun Sidodadi Desa Terentang Baru yang menggunakan produk kosmetik merek Batrisyia Herbal. Sampel dalam penelitian ini adalah masyarakat pengguna kosmetik Batrisyia Herbal, ukuran sampel yang dijadikan objek penelitian ini adalah seluruh dari jumlah populasi, menurut Arikunto (2010) jika populasi besar dapat diambil antara 10\%-15\% atau 20\%-25\% tetapi apabila populasi di bawah 100 maka sampel harus diambil dari keseluruhan jumlah populasi. Jumlah sampel yang digunakan dalam penelitian ini adalah keseluruhan dari populasi yaitu 56 orang.

\section{Metode Analisa Data}

Skala Likert

Skala Likert merupakan skala yang dipakai untuk mengukur sikap, pendapat dan persepsi seseorang/sekelompok orang tentang fenomena sosial (Sugiyono, 2001:220). Menurut Sugiyono (2001:225) analisa dilakukan dengan menggunakan nilai indeks yaitu dengan menentukan nilai besarnya kelas sebagai berikut :

$\begin{array}{ll}\text { Nilai Maksimum } & : 5 \\ \text { Nilai Minimum } & : 1 \\ \text { Rentang Skala (RS) } & =\frac{\text { Nilai Maksimum-Nilai Minimum }}{\text { Jumlah Indeks }} \\ \text { Rentang Skala } & =\frac{(5-1)}{5} \\ \text { Rentang Skala (RS) } & =0,8\end{array}$


Metode analisis data yang digunakan dalam penelitian ini adalah metode analisis deskriptif yaitu menggunakan teori sebagai landasan berpijak dan melihat kondisi yang ditemukan, kemudian dianalisis berdasarkan data dan berhadapan langsung dilapangan. Penulis memperoleh langsung data-data yang dibutuhkan berdasarkan dari keterangan dan informasi yang diberikan responden melalui kuisioner yang telah disebarkan.

Indikator-indikator diukur dengan skala penilaian Likert yang memiliki lima tingkat prefensi jawaban yang masing-masing mempunyai nilai skor 1-5 dengan rincian sebagai berikut :

$\begin{array}{lll}\text { Sangat Tidak Setuju } & = & 1 \\ \text { Tidak Setuju } & = \\ \text { Cukup Setuju } & =3 \\ \text { Setuju } & =4 \\ \text { Sangat Setuju } & =5\end{array}$

Skala Likert merupakan skala yang dipakai untuk mengukur sikap, pendapat dan persepsi seseorang/sekelompok orang tentang fenomena sosial (Sugiyono, 2001:220). Menurut Sugiyono (2001:225) analisa dilakukan dengan menggunakan nilai indeks yaitu dengan menentukan nilai besarnya kelas sebagai berikut :

Nilai Maksimum : 5

Nilai Minimum : 1

Rentang Skala $(\mathrm{RS})=\frac{\text { Nilai Maksimum-Nilai Minimum }}{\text { Jumlah Indeks }}$

Rentang Skala $\quad=\frac{(5-1)}{5}$

Rentang Skala (RS) $\quad=0,8$

Sehingga tabel indeks penilaiannya adalaah sebagai berikut:

Tabel 3.1

Tabel Indeks Penilaian Tentang Perilaku

\begin{tabular}{|c|c|}
\hline Nilai Indeks & Penilaian \\
\hline $1,00<\mathrm{x} \leq 1,80$ & Sangat Tidak Baik \\
\hline $1,80<\mathrm{x} \leq 2,60$ & Tidak Baik \\
\hline $2,60<\mathrm{x} \leq 3,40$ & Cukup Baik \\
\hline $3,40<\mathrm{x} \leq 4,20$ & Baik \\
\hline $4,20<\mathrm{x} \leq 5,00$ & Sangat Baik \\
\hline
\end{tabular}

Sumber : Arikunto 2010

Tabel 3.2

Tabel Indeks Penilaian Tentang Kepuasan

\begin{tabular}{|c|c|}
\hline Nilai Indeks & Penilaian \\
\hline $1,00<\mathrm{x} \leq 1,80$ & Sangat Tidak Puas \\
\hline $1,80<\mathrm{x} \leq 2,60$ & Tidak Puas \\
\hline $2,60<\mathrm{x} \leq 3,40$ & Cukup Puas \\
\hline $3,40<\mathrm{x} \leq 4,20$ & Puas \\
\hline $4,20<\mathrm{x} \leq 5,00$ & Sangat Puas \\
\hline
\end{tabular}


Tabel 3.3

Indeks Penilaian Tentang Loyalitas

\begin{tabular}{|c|c|}
\hline Nilai Indeks & Penilaian \\
\hline $1,00<\mathrm{x} \leq 1,80$ & Sangat Tidak Loyal \\
\hline $1,80<\mathrm{x} \leq 2,60$ & Tidak Loyal \\
\hline $2,60<\mathrm{x} \leq 3,40$ & Cukup Loyal \\
\hline $3,40<\mathrm{x} \leq 4,20$ & Loyal \\
\hline $4,20<\mathrm{x} \leq 5,00$ & Sangat Loyal \\
\hline
\end{tabular}

\section{HASIL DAN PEMBAHASAN}

\section{Karakteristik Responden Berdasarkan Pendidikan Terakhir}

Dalam penelitian ini karakteristik responden berdasarkan pendidikan bahwa 4 orang responden atau $7,14 \%$ yang pendidikannya SLTP/Sederajat, sebanyak 39 orang responden atau $69,64 \%$ yang pendidikannya SLTA/Sederajat, 1 orang responden atau 1,79\% yang pendidikannya Diploma, 12 orang responden atau 21,43\% yang pendidikannya S1.Dari tabel diatas dapat diketahui bahwa yang membeli produk kosmetik merek Batrisyia Herbal adalah responden yang mempunyai latar belakang pendidikannya SLTA/Sederajat yaitu sebanyak 39 orang.

\section{Karakteristik Responden Berdasarkan Pekerjaan Saat Ini}

Karakteristik responden berdasarkan pekerjaan menunjukkan bahwa 7 orang responden atau $12.5 \%$ yang pekerjaan saat ini menjadi ASN, 8 orang responden atau $14,29 \%$ yang pekerjaan saat ini menjadi Honorer, 26 orang responden atau 46,43\% yang pekerjaan saat ini menjadi IRT, 9 orang responden atau $16,07 \%$ yang pekerjaan saat ini menjadi mahasiswa, sebanyak 6 orang responden atau 10,71\% yang bekerja lain-lain.

Tanggapan Responden Tentang Perilaku Konsumen Dalam Membeli Kosmetik Merek Batrisyia Herbal di Dusun Sidodadi Desa Terentang Baru

Dari penelitian yang dilakukan, tanggapan responden terhadap kuisioner yang disebarkan dapat dilihat sebagai berikut: Perilaku konsumen dalam membeli kosmetik Batrisyia Herbal dapat dilihat dari tanggapan responden, yang diukur dari 6 pernyataan berikut ini. Tanggapan responden dapat dilihat pada tabel 5.1 berikut ini:

Tabel 5.1.Tanggapan Responden Mengenai Perilaku

\begin{tabular}{|c|l|c|c|c|c|c|c|c|}
\hline \multirow{2}{*}{ No Pernyataan } & \multicolumn{1}{|c|}{ Skor } & \multirow{2}{*}{ JML } & Indeks \\
\cline { 2 - 8 } 1 & $\begin{array}{l}\text { Produk Batrisyia Herbal kandungan } \\
\text { yang digunakan sesuai dengan } \\
\text { syariat islam }\end{array}$ & 20 & 19 & 17 & 0 & 0 & 227 & 4,05 \\
\hline 2 & $\begin{array}{l}\text { Produk Batrisyia Herbal wanginya } \\
\text { sangat khas }\end{array}$ & 15 & 19 & 22 & 0 & 0 & 217 & 3,87 \\
\hline 3 & $\begin{array}{l}\text { Kosmetik Batrisyia Herbal warna } \\
\text { warninya sangat elegan }\end{array}$ & 26 & 26 & 4 & 0 & 0 & 246 & 4,39 \\
\hline 4 & $\begin{array}{l}\text { Produk Batrisyia Herbal desain dan } \\
\text { Kombinasi warnanya sangat Serasi }\end{array}$ & 29 & 19 & 8 & 0 & 0 & 245 & 4,37 \\
\hline 5 & $\begin{array}{l}\text { Harga yang ditawarkan kosmetik } \\
\text { Batrisyia Herbal sesuai dengan } \\
\text { kebutuhan anda }\end{array}$ & 18 & 17 & 21 & 0 & 0 & 221 & 3,94 \\
\hline
\end{tabular}




\begin{tabular}{|c|l|l|l|l|l|l|l|l|}
\hline 6 & $\begin{array}{l}\text { Harga yang ditawarkan kosmetik } \\
\text { Batrisyia Herbal harga tidak } \\
\text { memberatkan anda }\end{array}$ & 18 & 19 & 19 & 0 & 0 & 223 & 3,98 \\
\hline \multicolumn{8}{|c|}{ Rata rata indek } \\
\hline
\end{tabular}

\section{Sumber : Data Primer diolah}

Berdasarkan tabel 5.1 diketahui tanggapan responden tentang perilaku yang dinyatakan dalam tabel menunjukkan hasil tertinggi adalah 4,39 dengan pernyataan "Kosmetik Batrisyia Herbal warna warninya sangat elegan", yang terendah 3,87 dengan pernyataan yaitu "Produk Batrisyia Herbal wanginya sangat khas", dan rata-rata indeks dari 6 pernyataan diatas adalah 4,10. Berdasarkan dari hasil rata-rata indeks diatas membuktikan bahwa tanggapan responden mengenai perilaku berada pada kategori baik.

Tanggapan Responden Tentang Kepuasan Konsumen Dalam Membeli Kosmetik Merek batrisyia Herbal di Dusun Sidodadi Desa Terentang Baru

Dari penelitian yang dilakukan, tanggapan responden terhadap kuisioner yang disebarkan dapat dilihat sebagai berikut: Kepuasan konsumen dalam membeli kosmetik Batrisyia Herbal dapat dilihat dari tanggapan responden, yang diukur dari 6 pernyataan berikut ini. Tanggapan responden dapat dilihat paada tabel 5.2 berikut ini:

Tabel 5.2. Tanggapan Responden Mengenai Kepuasan Konsumen

\begin{tabular}{|c|c|c|c|c|c|c|c|c|}
\hline \multirow[b]{2}{*}{ No } & \multirow[b]{2}{*}{ Pernyataan } & \multicolumn{5}{|c|}{ Skor } & \multirow[b]{2}{*}{ JML } & \multirow[b]{2}{*}{ Indeks } \\
\hline & & SS & S & CS & TS & $\begin{array}{c}\text { ST } \\
\text { S }\end{array}$ & & \\
\hline 1 & $\begin{array}{l}\text { Produk Batrisyia Herbal } \\
\text { bila dipakai tidak cepat } \\
\text { luntur }\end{array}$ & 24 & 22 & 10 & 0 & 0 & 238 & 4,25 \\
\hline 2 & $\begin{array}{l}\text { Produk Batrisyia Herbal } \\
\text { fungsinya untuk membuat } \\
\text { kulit cantik lebih alami } \\
\text { disbanding yang lain }\end{array}$ & 6 & 20 & 30 & 0 & 0 & 200 & 3,57 \\
\hline 3 & $\begin{array}{l}\text { Produk Batrisyia Herbal } \\
\text { sangat mudah digunakan } \\
\text { dikulit }\end{array}$ & 16 & 17 & 23 & 0 & 0 & 217 & 3,87 \\
\hline 4 & $\begin{array}{l}\text { Produk Batrisyia Herbal } \\
\text { yang diperoleh sesuai atau } \\
\text { melebihi dengan yang } \\
\text { diharapkan }\end{array}$ & 7 & 14 & 35 & 0 & 0 & 196 & 3,50 \\
\hline 5 & $\begin{array}{l}\text { Pelayanan membeli produk } \\
\text { Batrisyia Herbal sesuai } \\
\text { atau melebihi dengan yang } \\
\text { diharapkan }\end{array}$ & 14 & 25 & 17 & 0 & 0 & 221 & 3,94 \\
\hline 6 & $\begin{array}{lcr}\text { Fasilitas } & \text { penunjang } & \text { yang } \\
\text { didapat } & \text { sesuai } & \text { atau } \\
\text { melebihi } & \text { dengan } & \text { yang } \\
\text { diharapkan } & & \\
\end{array}$ & 14 & 18 & 24 & 0 & 0 & 214 & 3,82 \\
\hline & Rata rata & lek & & & & & 214 & 3,83 \\
\hline
\end{tabular}

Sumber : Data Primer diolah 
Berdasarkan tabel 5.2 diketahui hasil tanggapan responden tentang kepuasan yang dinyatakan dalam tabel menunjukkan hasil tertinggi adalah 4,25 dengan pernyataan yaitu "Produk Batrisyia Herbal bila dipakai tidak cepat luntur", yang terendah adalah 3,50 dengan pernyataan yaitu "Produk Batrisyia Herbal yang diperoleh sesuai atau melebihi dengan yang diharapkan", dan rata-rata indeks dari 6 pernyataan diatas adalah 3,83. Berdasarkan dari hasil rata-rata tabel diatas membuktikan bahwa tanggapan responden mengenai kepuasan berada pada kategori puas.

\section{Tanggapan Responden Tentang Loyalitas Konsumen Dalam Membeli Kosmetik Merek Batrisyia Herbal di Dusun Sidodadi Desa Terentang Baru}

Dari penelitian yang dilakukan, tanggapan responden terhadap kuisioner yang disebarkan dapat dilihat sebagai berikut: Loyalitas konsumen dalam membeli kosmetik Batrisyia Herbal dapat dilihat dari tanggapan responden, yang diukur dari 6 pernyataan berikut ini. Tanggapan responden dapat dilihat pada tabel 5.3 berikut ini:

Tabel 5.3. Tanggapan Responden Loyalitas

\begin{tabular}{|c|c|c|c|c|c|c|c|c|}
\hline \multirow{2}{*}{ No } & \multirow{2}{*}{ Pernyataan } & \multicolumn{5}{|c|}{ Skor } & \multirow{2}{*}{ JML } & \multirow{2}{*}{ Indeks } \\
\hline & & SS & $\mathrm{S}$ & $\mathrm{CS}$ & TS & STS & & \\
\hline 1 & $\begin{array}{lcr}\text { Anda } & \text { membeli } & \text { produk } \\
\text { Batrisyia } & \text { Herbal } & \text { karena } \\
\text { merasa } & \text { puas } & \text { ketika } \\
\text { menggunakannya } & \\
\end{array}$ & 26 & 27 & 3 & 0 & 0 & 247 & 4,41 \\
\hline 2 & $\begin{array}{lll}\text { Anda membeli } & \text { produk } \\
\text { Batrisyia Herbal } & \text { karena } \\
\text { pengaruh orang lain } & \end{array}$ & 35 & 12 & 9 & 0 & 0 & 250 & 4,46 \\
\hline 3 & $\begin{array}{lcr}\text { Anda membeli } & \text { produk } \\
\text { Batrisyia } & \text { Herbal } & \text { karena } \\
\text { kebiasaan } & & \\
\end{array}$ & 21 & 25 & 10 & 0 & 0 & 235 & 4,20 \\
\hline 4 & $\begin{array}{lcr}\text { Anda membeli } & \text { produk } \\
\text { Batrisyia } & \text { Herbal } & \text { karena } \\
\text { sesuai dengan } & \text { keadaan } \\
\text { ekonomi } & & \\
\end{array}$ & 9 & 18 & 29 & 0 & 0 & 204 & 3,64 \\
\hline 5 & $\begin{array}{l}\text { Anda membeli produk } \\
\text { Batrisyia Herbal karena } \\
\text { memiliki kualitas yang baik }\end{array}$ & 20 & 18 & 18 & 0 & 0 & 226 & 4,04 \\
\hline 6 & $\begin{array}{l}\text { Anda membeli produk } \\
\text { Batrisyia Herbal karena } \\
\text { banyak yang menjualnyas }\end{array}$ & 15 & 27 & 14 & 0 & 0 & 225 & 4,02 \\
\hline & Rata rata is & & & & & & 231 & 4,13 \\
\hline
\end{tabular}

Sumber : Data Primer diolah

Berdasarkan tabel 5.3 diketahui tanggapan responden tentang loyalitas yang dinyatakan dalam tabel menunjukkan hasil tertinggi adalah 4,46 dengan pernyataan yaitu "Anda membeli produk Batrisyia Herbal karena pengaruh orang lain", yang terendah adalah 3,64 dengan pernyataan yaitu "Anda membeli produk Batrisyia Herbal karena sesuai dengan keadaan ekonomi", dan rata-rata indeks dari 6 pernyataan diatas adalah 4,13. 
Berdasarkan dari hasil rata-rata indeks tabel diatas membuktikan bahwa tanggapan responden mengenai loyalitas berada pada kategori loyal.

\section{Analisis Perilaku, Kepuasan dan Loyalitas Konsumen Dalam Membeli Produk Kosmetik Merek Batrisyia Herbal di Dusun Sidodadi Desa Terentang Baru}

Berdasarkan penelitian yang dilakukan didapat rata-rata indeks mengenai perilaku yaitu 4,10 yang mana indeks ini termasuk dalam kategori baik, yang berarti bahwa perilaku mempengaruhi konsumen dalam membeli kosmetik Batrisyia Herbal dilihat dari kandungan produk yang digunakan sesuai dengan syariat islam, wanginya sangat khas, warna-warninya sangat elegan, desain dan kombinasinya sangat serasi, harga yang ditawarkan sesuai dengan kebutuhan dan harga tidak memberatkan. Rata-rata indeks mengenai kepuasan yaitu 3,83 yang mana indeks ini termasuk dalam kategori puas, yang berarti bahwa kepuasan mempengaruhi konsumen dalam membeli kosmetik Batrisyia Herbal dilihat dari Batrisyia Herbal jika dipakai tidak cepat luntur, fungsinya untuk membuat kulit cantik alami, sangat mudah digunakan dikulit, yang diperoleh sesuai dengan yang diharapkan, pelayanan membbeli sesuai dengan yang diharapkan dan fasilitas penunjang sesuai dengan yang diharapkan. Rata-rata indeks mengenai loyalitas yaitu 4,13 yang mana indeks ini termasuk dalam kategori loyal, yang berarti bahwa loyalitas mempengaruhi konsumen dalam membeli kosmetik Batrisyia Herbal dilihat dari merasa puas ketika menggunakannya, memeli produk karena pengaruh orang lain, membeli karena kebiasaan, membeli karena keadaan ekonomi, membeli karena memiliki kualitas yang baik dan karena banyak yang menjualnya.

\section{SIMPULAN DAN SARAN \\ Simpulan}

Simpulan yang dapat diambil dari penelitian ini adalah:

1. Tanggapan responden terhadap perilaku konsumen didapat rata-rata indeks 4,10 dimana indeks ini termasuk dalam kategori baik.

2. Tanggapan responden terhadap kepuasan konsumen didapat rata-rata indeks 3,83 dimana indeks ini termasuk dalam kategori puas.

3. Tanggapan responden terhadap loyalitas konsumen didapat rata-rata indeks 4,13 dimana indeks ini termasuk dalam kategori loyal.

4. Tanggaan responden mengenai perilaku, kepuasan dan loyalitas terdapat nilai rata-rata indeks yang tertinggi adalah tanggapan responden tentang loyalitas dengan nilai ratarata indeks 4,13 dimana indeks ini termasuk dalam kategori loyal, yang berarti bahwa loyalitas mempengaruhi konsumen dalam membeli kosmetik Batrisyia Herbal dilihat dari merasa puas ketika menggunakannya, memeli produk karena pengaruh orang lain, membeli karena kebiasaan, membeli karena keadaan ekonomi, membeli karena memiliki kualitas yang baik dan karena banyak yang menjualnya.

\section{Saran}

Untuk meningkatkan daya beli produk kosmetik merek Batrisyia Herbal perusahaan harus dapat memahami perilaku, kepuasan dan loyalitas konsumen apa saja agar konsumen dapat terus berlangganan membeli produk tersebut.

\section{DAFTAR PUSTAKA}

Arikunto, 2010. Prosedur Penelitian, Suatu Pendekatan Praktek. Rineka Cipta: Jakarta. Boone dan Kurtz. 2007. Pengantar Bisnis Kontemporer. Salemba Empat: Jakarta. 
Dharmmesta, Basu Swastha dan Hani Handoko. 2013. Manajemen Pemasaran, Analisis Perilaku Konsumen. Liberty: Jakarta.

Durianto, D, Sugiarto dan Joko, B.L. 2004. Brand Equity Ten: Stategi memimpin Pasar. Jakarta: PT Gramedia Pustaka Utama.

Fitriani, Eni. 2017. Pembelian Produk Kosmetik Wardah: Fakultas Ekonomi dan Bisnis Universitas Halu Uleo Kendari.

Ghozali, Imam. 2011. Aplikasi Analisis Multivariate Dengan Program IBM SPSS 19. Edisi V. Badan Penerbit Universitas Diponegoro: Semarang.

Kotler dan Keller. 2009. Manajemen Pemasaran Jilid I (edisi 13). Jakarta: Erlangga

Kotler, Philip dan Kevin Lane Keller. 2006. Manajemen Pemasaran. Prentice Hall: London.

Lina, Amalia. 2017. Ismail, B, Tajuddin, M.T, Armia, R.N, Samsudin, M.M, Zain, R.A dan Derani, N. 2012. The Relationship Between Store Brand and Customer Loyalty in Retailing in Malaysia. Asian Social Science, 8 (2), 171-184.

Malau, Harman, Ph.D. 2017. Manajemen Pemasaran: Teori dan Aplikasi Pemasaran Era Tradisional sampai Era Modernisasi Global. Bandung: Alfabeta.

Setiadi, J. Nugroho. 2003. Perilaku Konsumen: Konsep dan Implikasi Untuk Strategi dan Penelitian Pemasaran. Jakarta: Prenada Media.

Sri, Yuniarti V, S.E., M.M. 2015. Perilaku Konsumen Teori dan Praktik. Bandung: Pustaka Setia

Sugiyono. 2011. Metode Penelitian Kuantitatif, Kualitatif R\&D. Afabeta: Bandung.

Tenenhaus, M, Esposito, V, Chatelin, Y, Lauro, C. 2004. PLS Path Modeling. Computational Statistics \& Data Analysis, 48 (2005), 159-205.

Tjiptono, Fandy, 2004, Marketing Scales, Penerbit : Andi, Yogyakarta

Tjiptono, Fandy, 2006, Pemasaran Jasa, edisi pertama, cetakan kedua, penerbit: Bayumedia Publishing, Malang

Wasitaatmadja, S. M. 1997. Penuntun Ilmu Kosmetik Medik. Universitas Indonesia: Jakarta. 